\title{
Iron overload and iron chelating agent exposure in anemia-associated outer retinal degeneration: a case report and review of the literature
}

\author{
Mohamed Belmouhand ${ }^{1,2^{*}}$ (D), Christina Eckmann-Hansen ${ }^{1,2}$, Tomas Ilginis ${ }^{1}$, Eva Birgitte Leinøe ${ }^{3}$,
}

Bo Kok Mortensen ${ }^{4}$ and Michael Larsen ${ }^{1,2}$

\begin{abstract}
Background: Deferoxamine retinopathy is the informally designated term used to describe a characteristic pattern of outer retinal degeneration in iron-overloaded chronic anemia patients who are treated with deferoxamine. We hypothesize that insufficiently treated iron overloading and not only deferoxamine is the cause of the retinal degeneration. Our case report is based on exposure histories of two anemia patients and literature review.

Case presentation: Both anemia patients presented with bilateral visual loss secondary to photoreceptor and retinal pigment epithelium degeneration. Chart review showed that visual loss came after a year-long slow, and rather monotonous rise in plasma ferritin concentrations, with no obvious relation to iron chelator exposure. In one patient, the onset of symptomatic visual loss came after a bout of fever followed by two additional febrile episodes, all accompanied by plasma ferritin spikes. Adjustment of iron chelation therapy did not improve visual function. Experimental studies clearly show that both systemic and intraocular exposure to iron ions can induce retinal degeneration.

Conclusion: The available evidence indicates that retinal degeneration in chronic anemia patients treated by deferoxamine is cause by insufficient iron chelation, not by deferoxamine. The actual role of iron chelating agents may be to promote a long enough survival to allow the slow development of retinal siderosis.
\end{abstract}

Keywords: Anemia, Iron chelation, Iron overload, Deferoxamine, Retinopathy, Case report

\section{Introduction}

The iron content of the human body is regulated at the level of intestinal absorption. There is no regulated form of excretion in individuals with excessive iron store. This can lead to iron toxicity in patients with a chronic need for blood transfusions. If untreated, many patients with

\footnotetext{
* Correspondence: mohamed.belmouhand@regionh.dk

'Department of Ophthalmology, Rigshospitalet, Copenhagen University Hospital, Glostrup, Denmark

${ }^{2}$ Department of Clinical Medicine, Faculty of Healthy and Medical Science, University of Copenhagen, Copenhagen, Denmark

Full list of author information is available at the end of the article
}

hematological disease will therefore die from heart and liver failure within 10 years [1]. To avoid fatal cardiac complications of hemosiderosis (systemic iron overload), individuals with chronic transfusion-treated anemia are therefore treated with an iron chelating agent.

The introduction of the iron chelating agent deferoxamine in 1968 was followed by a marked reduction in mortality from hemosiderosis. Subsequently, the term deferoxamine retinopathy was coined for a characteristic pigmented degeneration of the outer retina with annular visual defects and night blindness that was seen among

(c) The Author(s). 2021 Open Access This article is licensed under a Creative Commons Attribution 4.0 International License, which permits use, sharing, adaptation, distribution and reproduction in any medium or format, as long as you give appropriate credit to the original author(s) and the source, provide a link to the Creative Commons licence, and indicate if changes were made. The images or other third party material in this article are included in the article's Creative Commons licence, unless indicated otherwise in a credit line to the material. If material is not included in the article's Creative Commons licence and your intended use is not permitted by statutory regulation or exceeds the permitted use, you will need to obtain permission directly from the copyright holder. To view a copy of this licence, visit http://creativecommons.org/licenses/by/4.0/. The Creative Commons Public Domain Dedication waiver (http://creativecommons.org/publicdomain/zero/1.0/) applies to the data made available in this article, unless otherwise stated in a credit line to the data. 
chronic anemia patients treated with an iron chelating agent (e.g. deferoxamine) [2, 3]. Several studies, primarily case-reports, have suggested that iron chelators may cause retinopathy [3-7]. However, other studies have presented results that contradict this notion [8, 9], and the demonstration of a potential role of trace element imbalance in optic nerve degeneration further complicates the evaluation of visual loss in patients suffering from chronic anemia [10]. Finally, the potential role of iron in inducing retinal degeneration has received little attention in the context of chronic anemia management.

Human retinal pigment epithelium (RPE) cells contain transferrin receptors that enable endocytosismediated iron uptake from the choroid, and iron is known to be toxic to the retina, especially the RPE $[11,12]$. The degenerative damage is believed to originate from iron-induced oxidative stress [12]. We therefore hypothesize that prolonged hemosiderosis plays a major role in the development of retinopathy in transfusion-dependent anemia patients, alone or in combination with iron chelating agents.

The aim of the study was to examine iron levels and deferoxamine treatment in two patients with chronic anemia before, during and after vision loss to more accurately determine the role of hemosiderosis in what is commonly called deferoxamine retinopathy. We have reviewed the evidence base of this nosological entity in the light of data from two patients with chronic anemia who consented to having their data published.

\section{Case presentation}

\section{Patient 1}

A 72-year-old man presented with blurred vision in both eyes beginning 1 week earlier as a dark, partially transparent area in the center of both visual fields. The dark area gradually expanded and changed to a pericentral dark ring in both eyes. He had suffered from aplastic anemia for 4 years and received one blood transfusion per week for 8 months when he presented. He had also received five infusions of $301 \mathrm{mg}$ antithymocyte globulin 1 month before the onset of visual loss (Fig. 1) and oral deferasirox beginning 4 months earlier. Deferasirox was discontinued after 1 month due to renal impairment and changed to deferoxamine infusion 1 month prior to visual loss. Past medical history included appendectomy (21 y), encephalitis (42 y), bilateral cataract surgery with pseudophakia $(51 \mathrm{y})$ and curative treatment of prostate cancer $(69$ y). Best-corrected Snellen visual acuity (BCVA) was 0.6 in the right eye and 0.9 in the left eye, a serous detachment of the macula was found in both eyes and applanation tonometry was normal. Visual acuity deteriorated to 0.3 in both eyes 3 months later. A presumptive diagnosis of deferoxamine retinopathy prompted a switch to oral deferiprone, but visual acuity decreased to worse than 0.1 in both eyes over the following year. From half a year before presentation to half a year after presentation, plasma ferritin - a surrogate measure of iron stores - had ranged from 2000 to 7230 $\mathrm{ng} / \mathrm{mL}$ (SI: 2000 to $7230 \mu \mathrm{g} / \mathrm{L}$ ), reference range $15-320$ $\mathrm{ng} / \mathrm{mL}$, with prominent peaks immediately before and after the onset of visual loss (Fig. 1). Patchy visual field

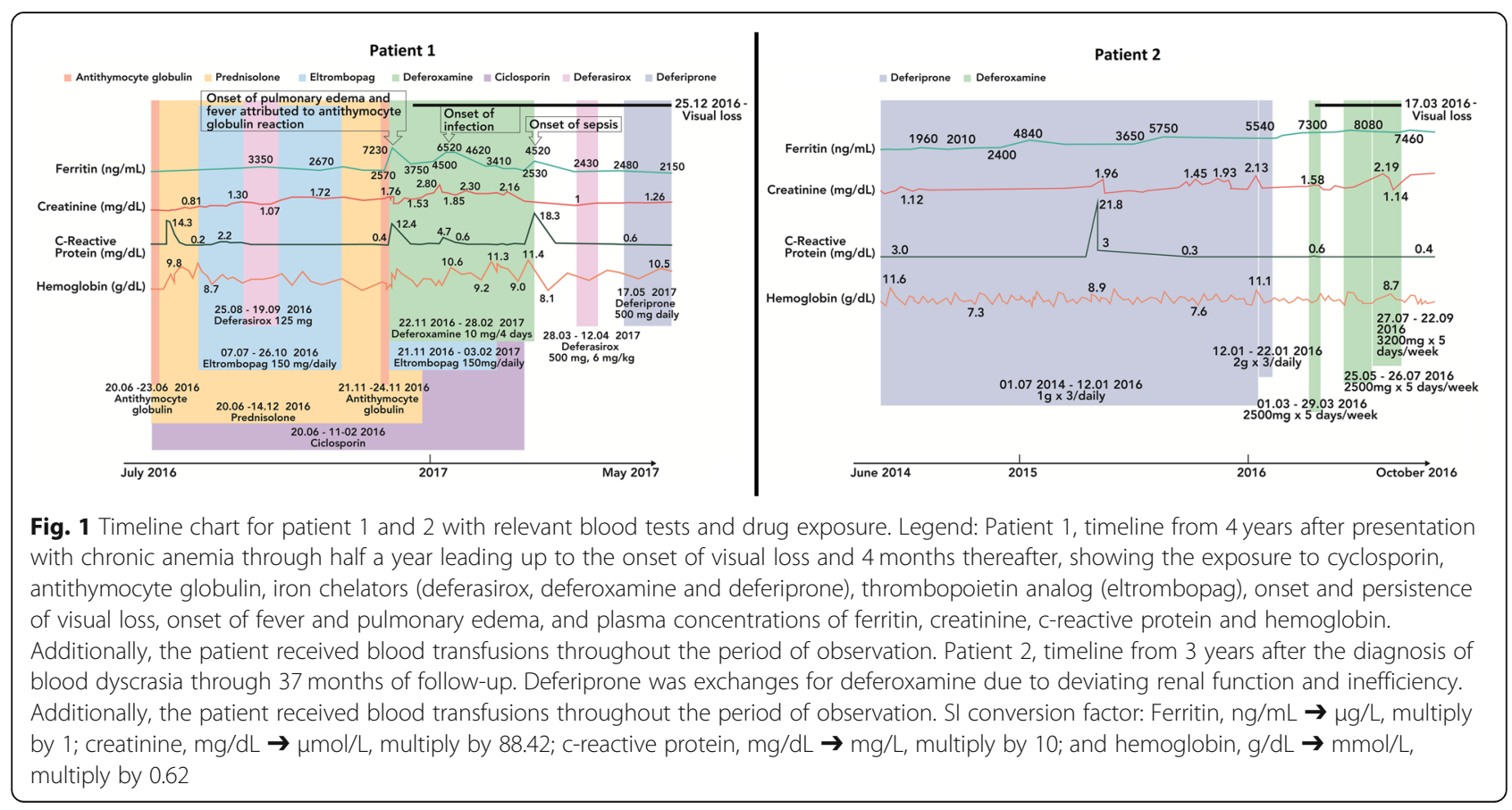


sensitivity loss (Fig. 2) was seen corresponding to hyperand hypofluorescent degeneration of the outer retina in both maculae (Fig. 3) and severely reduced cone photoreceptor density out 14 degrees from the foveola (Fig. 4). There were no other signs of hemosiderosis.

\section{Patient 2}

A 70-year-old male erythropoiesis-deficient anemia patient with floaters, flashes and poor color vision was seen with BCVA 0.9 in the right eye and 1.0 in the left eye. He had previously been diagnosed with

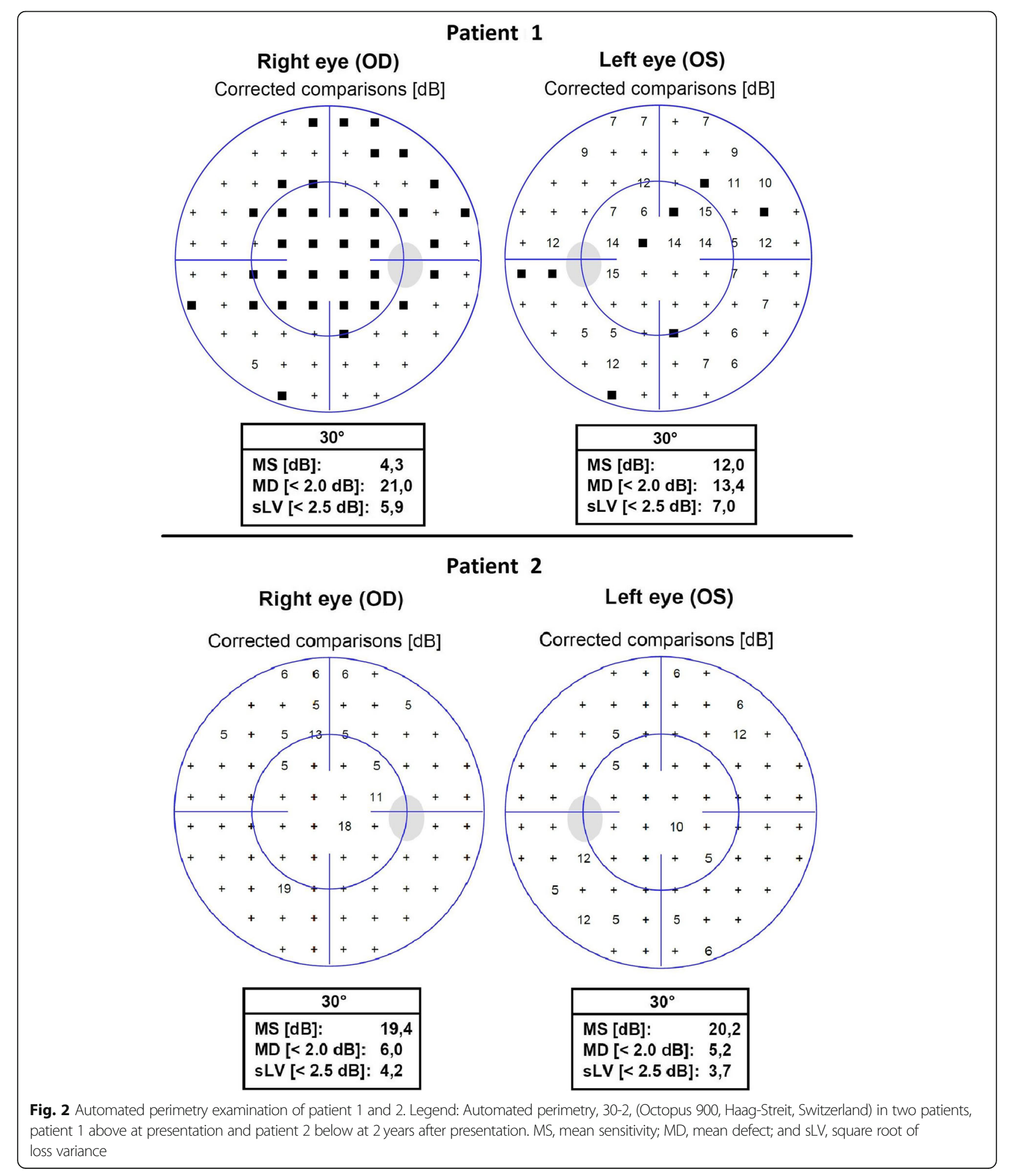




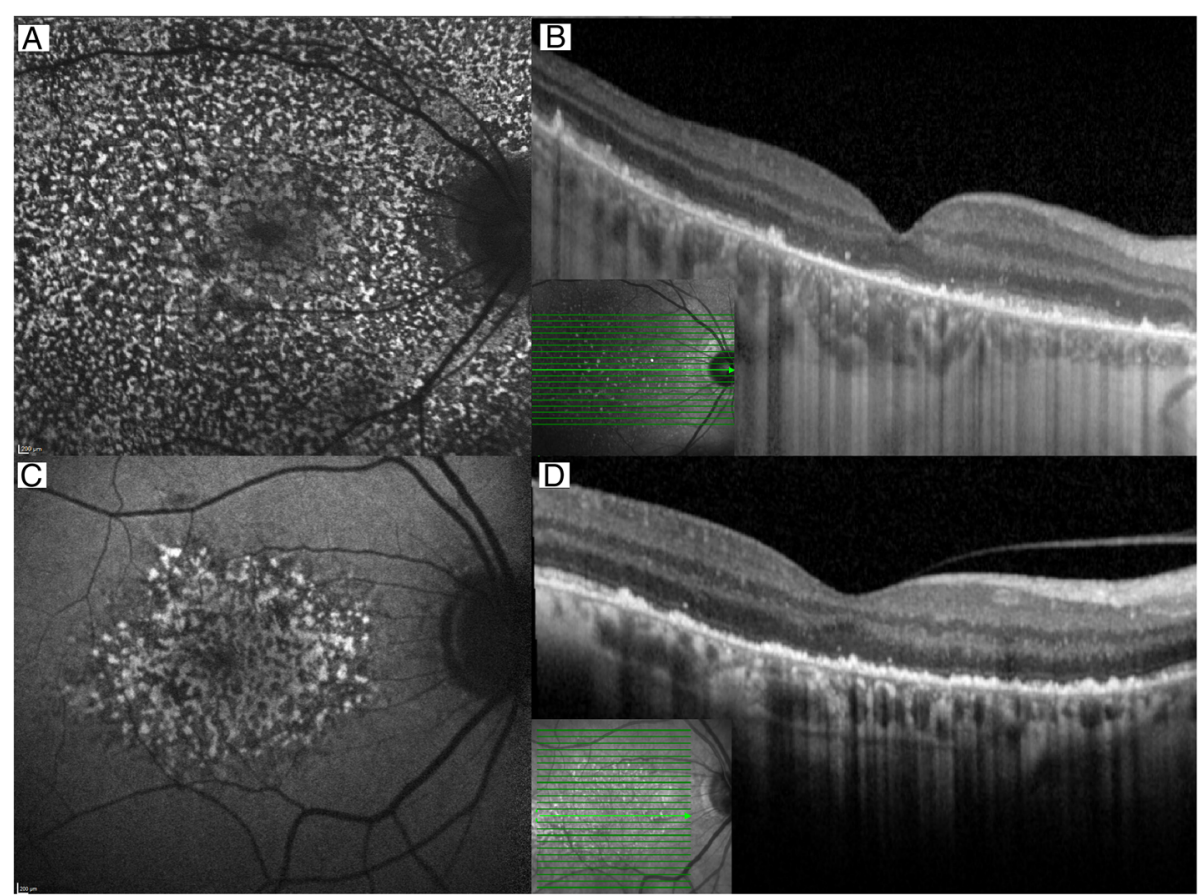

Fig. 3 Optical coherence tomography and blue light fundus autofluorescence imaging of retinal defects. Legend: In patient 1 ( $A+B)$, a diffuse dotted blue light fundus autofluorescence of the right eye shows widespread defects in the whole macula (A). The corresponding horizontal transfoveal optical coherence tomography shows degeneration and irregularities in the outer retina (B). In patient $2(C+D)$, a more localized defect is visible in the parafoveal region on blue light fundus autofluorescence (C). The optical coherence tomography shows the same outer retinal defects as in case 1 but temporally an intact outer retina is seen (D). In case 1 the images were acquired during initial visit, and in case 2 the images were acquired at follow-up 6 months after initial visit. Scans were acquired on Spectralis OCT2 (Heidelberg Engineering, Heidelberg, Germany)

type 2 diabetes mellitus (57 y), hypertension (57 y), diabetic nephropathy (68 y) and myelodysplastic syndrome with ring sideroblasts $(65 \mathrm{y})$. Blood transfusions had been administered from the past 2 years prior and was continued after the onset of visual symptoms. Deferiprone, administered until 8 months earlier, had been switched to deferoxamine due to renal impairment (Fig. 1). A tentative diagnosis of vitreous degeneration was made, but 6 months later BCVA had dropped to 0.2 in both eyes. The suspicion that deferoxamine was the cause prompted discontinuation of this drug without chelator substitution. One year later BCVA had increased to 0.8 in the right eye and 0.4 in the left eye. It then fell to 0.4 in both eyes when seen 55 months after presentation, when geographic atrophy was seen in the left macula. Over the 6 years up to his most recent visit, plasma ferritin had ranged from 1500 to $10,030 \mathrm{ng} / \mathrm{mL}$, with a peak near the onset of visual loss (Fig. 1). Visual field sensitivity was moderately diffusely reduced (Fig. 2) and both maculae showed granular hyper- and hypoautofluorescence with corresponding photoreceptor and pigment epithelium atrophy (Figs. 3 and 4).

\section{Discussion and conclusions}

The outer retinal degeneration seen in our two patients fits the description of what is called deferoxamine retinopathy. It is remarkable, however, that neither case showed a clear temporal association between iron chelator exposure, disease duration or disease severity, and retinal degeneration. Remarkably, the onset of subjective visual loss occurred on the chronically rising slopes of plasma ferritin concentration curves that had exceeded the recommended maximum of $1000 \mathrm{ng} / \mathrm{mL}$ for years [13]. While this maximum has been set to safeguard the heart, there is insufficient data to estimate the level of ferritin that is safe for the retina. We did not observe any uniform pattern of changes in retinal function or structure and fluctuations in hemoglobin or c-reactive protein.

Competing with the notion that deferoxamine in itself should be retinotoxic $[4,14]$, there is evidence that iron overload can induce outer retinal degeneration by promoting the production of reactive oxygen species and an inherent increase in oxidative stress [12, 15]. Independent of the blood-retina barrier, human RPE cells have an abundance of transferrin receptors which permit 


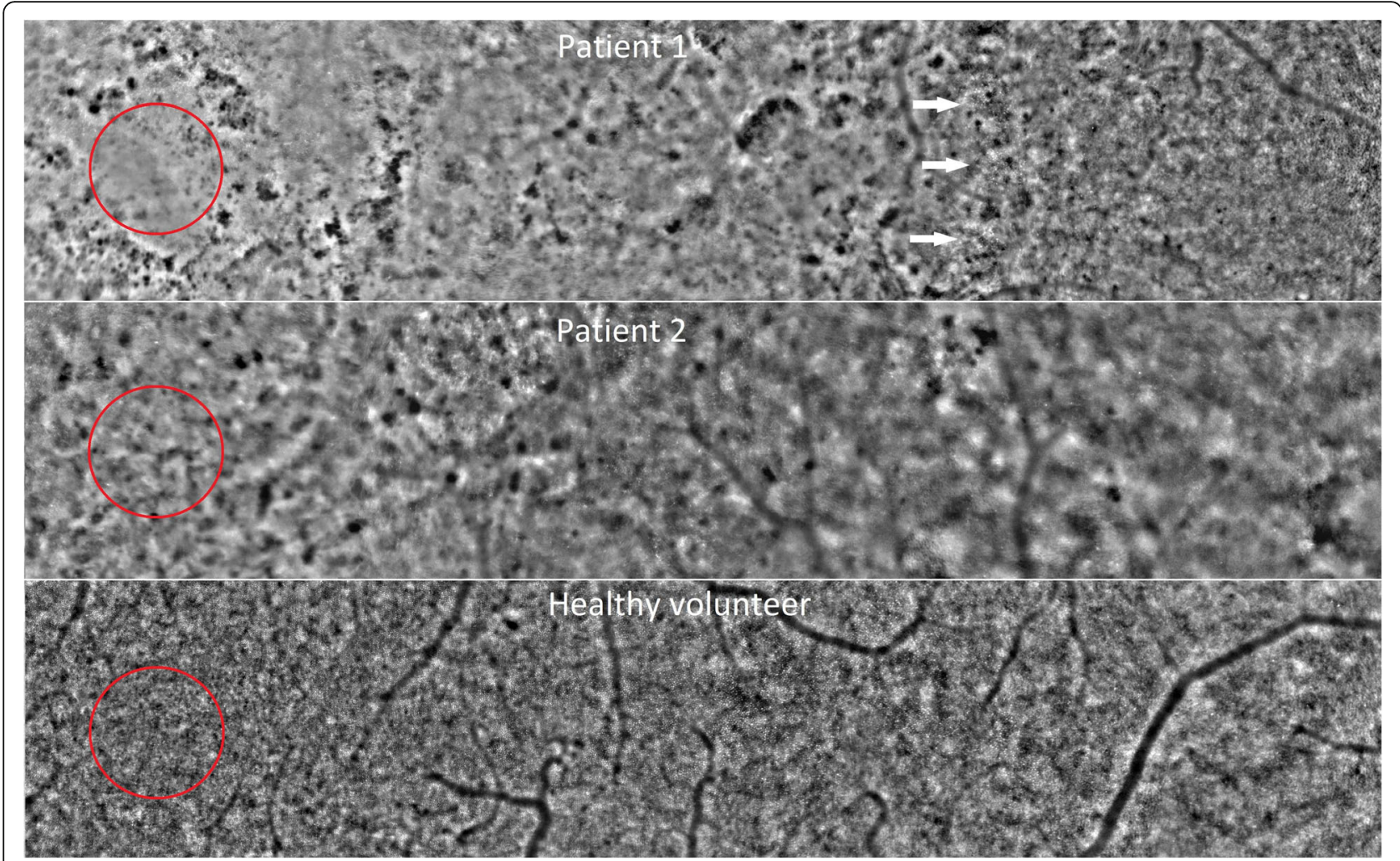

Fig. 4 Adaptive optics fundus photography of photoreceptor mosaic. Legend: Patient 1 (A), patient 2 (B) and a healthy age-matched volunteer (C), spanning from the fovea (indicated by red circles) to a position 14 degrees temporal of the foveal center. Patient 1 is remarkable for having a transitional zone (white arrows) between injured granular retina on the foveal side and more normal retina on the temporal side. Patient 2 shows patchy absence or attenuation of the photoreceptor matrix. The healthy volunteer had a normal photoreceptor distribution. The images of patient 1 and 2 were recorded 5 and 4 months, respectively, after presentation. Acquired on RTX-1 (Imagine Eyes, Orly, France) on floodilluminated adaptive optics fundus photography

endocytosis-mediated iron uptake from the choroid [11]. Of particular note, our patients' ocular characteristics are comparable those seen in hemochromatosis [16], in experimental intraocular iron toxicity $[17,18]$ and in intraocular ferrous foreign body retention, where the functional deficit is partially reversible [19], as was the visual loss in our patient 2 .

The mechanism or etiology of a possible deferoxamineinduced toxicity is not understood; however, it is plausible that deferoxamine affects iron mobilization locally in the retina and thereby causes atrophy. Furthermore, clinical cases of presumed deferoxamine retinopathy have all occurred in patients with iron overload during some period of their disease [3], and rabbits with intraocular iron foreign bodies are protected from retinal degeneration by deferoxamine [20]. Deferiprone, an oral iron chelator, was shown to protect against retinal degeneration induced by systemic iron overload in mice [21, 22]. While deferoxamine can depress the electroretinogram, the effect is transient and was observed in patients with concurrent hemosiderosis [3].
Preclinical data from animal studies shows that iron overload can induce retinal damage [17, 23-25]. In addition, iron overload can also accelerate cell death in rats exposed to partial nerve head crush [26]. Knock-out of TIM2, the receptor for $\mathrm{H}$-ferritin in Müller cells of the mouse retina, has led to iron overload and consequently production of reactive oxygen species and subsequent retinal degeneration [27]. Salvianic acid A, an extract from Chinese herbs, and Puerarin are agents used in alternative medicine that have been shown to ameliorate iron overload-induced toxicity in mice [28, 29]. The positive actions of these two drugs are believed to be through regulation of iron-handling proteins that possibly aid in iron chelation and attenuation of oxidative stress. These two drugs have not been tested in humans with hemosiderosis.

Ferroptosis, a recently described cell death mechanism that dependents on an abundant concentration of iron [30], may theoretically be involved in retinal damage by promoting retinal cell death in hemosiderosis. Thus, a study has found evidence that ferroptosis contributed to 
cell death in cultured human RPE cells exposed to iron overload, and that deferoxamine attenuated the rate of cell death [31].

Only a speculative case association with retinal degeneration has been reported for deferasirox and none for deferiprone, which are two alternative clinical iron chelating drugs [32]. Thus, the analysis of clinical cases may potentially be confounded by interaction between a reversible functional effect of deferoxamine and a more permanent effect of iron on the retina [3]. Notably, most clinical reports linking deferoxamine with retinal degeneration have not accounted for ferritin levels prior to, during or after vision loss. We therefore suspect that ferritin spikes or burst of cytokine release from disintegrating T-cells, as seen during antithymocyte therapy [33], may promote retinal degeneration, as may the natural accumulation of iron in the retina with aging [34]. Whether antithymocyte therapy or other unknown dysfunction in iron metabolism caused the retinal damage in our patient no. 1 to become irreversible can only be hypothesized.

Our two cases expand OCT-based demonstrations of attenuation and irregularity of the photoreceptor and RPE layers in the macula [5, 14]. Cone photoreceptor counts in affected areas were about half of what is normal, with considerable focal variations confined to the area within the temporal vascular arcades.

The complexity of the typical clinical course in anemia limits the retrospective analysis of causality in retinopathy cases, of whom the ones with the highest iron load are the ones who received the most intensive chelation therapy. Although our two cases were highly valuable in understanding the complexity of chronic anemia and retinopathy, we cannot generalize or establish causeeffect relationships based on our findings.

In conclusion, retinal injury in iron-overload anemia should not unreservedly be attributed to iron chelation therapy. Insufficient iron chelation should be considered as an alternative etiology. Proactive eye examination, meticulous clinical documentation and awareness of the guideline upper plasma ferritin level of $1000 \mathrm{ng} / \mathrm{mL}$ may help enable rational analysis of cases and reduction of the incidence of retinal degeneration in chronic anemia patients.

\section{Abbreviations}

BCVA: Best-corrected visual acuity; RPE: Retinal pigment epithelium

\section{Acknowledgements}

Not applicable.

\section{Authors' contributions}

Concept and design: ML, CEH and MB. Acquisition, analysis or interpretation of data: All authors. Drafting of the manuscript: MB, CEH and ML. Critical revision of the manuscript for important intellectual content: TI, EL and BKM. Final approval of the manuscript: All authors.

\section{Funding}

The study was supported by the European Union under H2020-EU.2.1.1. - ID 780989 (MERLIN); Rigshospitalet(grant E-23334-02); P. Carl Petersens Fond (grant 19102); Aase og Ejnar Danielsens Fond (grant 18-10-0698); Helsefonden (grant 19-B-0063); Beckett Fonden (grant 19-2-3490); and Einar Willumsens Mindelegat (grant 500028). None of the above-mentioned sources has had any role in the design, analysis or interpretation of data and in writing the manuscript.

\section{Availability of data and materials}

All data generated or analyzed during this study are included in this published article.

\section{Declarations}

Ethics approval and consent to participate

Ethics approval was not necessary for this case report.

\section{Consent for publication}

Both study participants gave their oral and written informed consent for publication.

\section{Competing interests}

$\mathrm{ML}$ has consulted, spoken or been a trial investigator for Novartis, Chiesi, Allergan, Bayer, Alcon, AbbVie, Biogen, Novo Nordisk, Eli Lilly, Spark

Therapeutics, Nightstar, Sanofi and Roche.

\section{Author details}

'Department of Ophthalmology, Rigshospitalet, Copenhagen University Hospital, Glostrup, Denmark. 'Department of Clinical Medicine, Faculty of Healthy and Medical Science, University of Copenhagen, Copenhagen, Denmark. ${ }^{3}$ Department of Hematology, Rigshospitalet, Copenhagen University Hospital, Copenhagen, Denmark. ${ }^{4}$ Department of Hematology, Herlev and Gentofte Hospital, Copenhagen University Hospital, Herlev, Denmark.

Received: 1 February 2021 Accepted: 29 June 2021

Published online: 13 July 2021

\section{References}

1. Borgna-Pignatti C, Rugolotto S, De Stefano P, et al. Survival and complications in patients with thalassemia major treated with transfusion and deferoxamine. Haematologica. 2004;89(10):1187-93.

2. Viola F, Barteselli $G$, Dell'Arti $L$, et al. Multimodal imaging in deferoxamine retinopathy. Retina. 2014;34(7):1428-38. https://doi.org/10.1097/IAE. 0000000000000073

3. Davies SC, Marcus RE, Hungerford JL, Miller MH, Arden GB, Huehns ER. Ocular toxicity of high-dose intravenous desferrioxamine. Lancet. 1983; 2(8343):181-4. https://doi.org/10.1016/s0140-6736(83)90170-8.

4. Di Nicola M, Barteselli G, Dell'Arti L, Ratiglia R, Viola F. Functional and structural abnormalities in Deferoxamine retinopathy: a review of the literature. Biomed Res Int. 2015;2015:249617-2. https://doi.org/10.1155/201 5/249617.

5. Van Bol L, Alami A, Benghiat FS, Rasquin F. Spectral domain optical coherence tomography findings in early deferoxamine maculopathy: report of two cases. Retinal Cases and Brief Reports. 2014;8(2):97-102. https://doi. org/10.1097//CB.0000000000000013.

6. Gelman R, Kiss S, Tsang SH. Multimodal imaging in a case of deferoxamineinduced maculopathy. Retin Cases Brief Rep. 2014;8(4):306-9. https://doi. org/10.1097/ICB.0000000000000059.

7. Georgakopoulos CD, Tsapardoni F, Kostopoulou EV, Makri OE. Pattern dystrophies in patients treated with deferoxamine: report of two cases and review of the literature. BMC Ophthalmol. 2018;18(1):246. https://doi.org/1 $0.1186 / \mathrm{s} 12886-018-0911-2$

8. Nuzzi R, Geronazzo G, Tridico F, Nuzzi A, Caselgrandi P, Piga AG. Long-term effects of Iron chelating agents on ocular function in patients with thalassemia major. Clin Ophthalmol. 2021;15:2099-109. https://doi.org/1 0.2147/OPTH.S300974.

9. Bhoiwala DL, Dunaief JL. Retinal abnormalities in $\beta$-thalassemia major. Surv Ophthalmol. 2016;61(1):33-50. https://doi.org/10.1016/.survophthal.2015.08. 005. 
10. Kamińska A, Romano GL, Rejdak R, et al. Influence of Trace Elements on Neurodegenerative Diseases of The Eye-The Glaucoma Model. Int J Mol Sci. 2021;22(9). https://doi.org/10.3390/ijms22094323.

11. Hunt RC, Dewey A, Davis AA. Transferrin receptors on the surfaces of retinal pigment epithelial cells are associated with the cytoskeleton. J Cell Sci. 1989:92(Pt 4):655-66. https://doi.org/10.1242/jcs.92.4.655.

12. He $X$, Hahn P, lacovelli J, Wong R, King C, Bhisitkul R, et al. Iron homeostasis and toxicity in retinal degeneration. Prog Retin Eye Res. 2007;26(6):649-73. https://doi.org/10.1016/j.preteyeres.2007.07.004.

13. Cappellini MD CA, Eleftheriou A, et al. Guidelines for the clinical Management of Thalassaemia, $2^{\text {nd }}$ revised edition. Thalassaemia International Federation; 2008.

14. Wu CH, Yang CP, Lai CC, Wu WC, Chen YH Deferoxamine retinopathy: spectral domain-optical coherence tomography findings BMC Ophthalmol 2014;14:88. doi:https://doi.org/10.1186/1471-2415-14-88, 1.

15. Gnana-Prakasam JP, Martin PM, Smith SB, Ganapathy V. Expression and function of iron-regulatory proteins in retina. IUBMB Life. 2010;62(5):363-70. https://doi.org/10.1002/iub.326.

16. Zerbib J, Pierre-Kahn V, Sikorav A, Oubraham H, Sayag D, Lobstein F, et al. Unusual retinopathy associated with hemochromatosis. Retin Cases Brief Rep. 2015;9(2):190-4. https://doi.org/10.1097/icb.0000000000000135.

17. Masciulli $L$, Anderson DR, Charles S. Experimental ocular siderosis in the squirrel monkey. Am J Ophthalmol. 1972;74(4):638-61. https://doi.org/10.101 6/0002-9394(72)90826-4.

18. Declercq SS, Meredith PC, Rosenthal AR. Experimental siderosis in the rabbit: correlation between electroretinography and histopathology. Arch Ophthalmol. 1977;95(6):1051-8. https://doi.org/10.1001/archopht.1977.04450060138014.

19. Kannan NB, Adenuga OO, Rajan RP, Ramasamy K. Management of Ocular Siderosis: visual outcome and Electroretinographic changes. J Ophthalmol. 2016;2016:7272465. https://doi.org/10.1155/2016/7272465.

20. Declercq SS. Desferrioxamine in ocular siderosis: a long-term electrophysiological evaluation. Br J Ophthalmol. 1980;64(8):626-9. https:// doi.org/10.1136/bjo.64.8.626.

21. Hadziahmetovic M, Song Y, Wolkow N, lacovelli J, Grieco S, Lee J, et al. The oral iron chelator deferiprone protects against iron overload-induced retinal degeneration. Invest Ophthalmol Vis Sci. 2011;52(2):959-68. https://doi.org/1 0.1167/iovs.10-6207.

22. Song D, Zhao L, Li Y, Hadziahmetovic M, Song Y, Connelly J, et al. The oral iron chelator deferiprone protects against systemic iron overload-induced retinal degeneration in hepcidin knockout mice. Invest Ophthalmol Vis Sci. 2014;55(7):4525-32. https://doi.org/10.1167/iovs.14-14568.

23. Hahn P, Qian Y, Dentchev T, Chen L, Beard J, Harris ZL, et al. Disruption of ceruloplasmin and hephaestin in mice causes retinal iron overload and retinal degeneration with features of age-related macular degeneration. Proc Natl Acad Sci U S A. 2004;101(38):13850-5. https://doi.org/10.1073/pnas.0405146101.

24. Chaudhary K, Promsote W, Ananth S, Veeranan-Karmegam R, Tawfik A, Arjunan $\mathrm{P}$, et al. Iron overload accelerates the progression of diabetic retinopathy in association with increased retinal renin expression. Sci Rep. 2018;8(1):3025. https://doi.org/10.1038/s41598-018-21276-2.

25. Song D, Dunaief $J$ L. Retinal iron homeostasis in health and disease. Front Aging Neurosci. 2013;5:24. https://doi.org/10.3389/fnagi.2013.00024.

26. Thaler S, Fiedorowicz M, Rejdak R, Choragiewicz TJ, Sulejczak D, Stopa P, et al. Neuroprotective effects of tempol on retinal ganglion cells in a partial optic nerve crush rat model with and without iron load. Exp Eye Res. 2010; 90(2):254-60. https://doi.org/10.1016/j.exer.2009.10.013.

27. Valença A, Mendes-Jorge L, Bonet A, Catita J, Ramos D, Jose-Cunilleras E, et al. TIM2 modulates retinal iron levels and is involved in blood-retinal barrier breakdown. Exp Eye Res. 2021;202:108292. https://doi.org/10.1016/j. exer.2020.108292.

28. Song Q, Zhang F, Han X, Yang Y, Zhao Y, Duan J. Ameliorative effects and mechanisms of salvianic acid a on retinal iron overload in vivo and in vitro. Exp Eye Res. 2021;209:108642. https://doi.org/10.1016/j.exer.2021.108642.

29. Song Q, Zhao Y, Li Q, Han X, Duan J. Puerarin protects against iron overloadinduced retinal injury through regulation of iron-handling proteins. Biomed Pharmacother. 2020;122:109690. https://doi.org/10.1016/j.biopha.2019.109690.

30. Li J, Cao F, Yin H-L, et al. Ferroptosis: past, present and future. Cell Death \& Disease. 2020;11(2):88. https://doi.org/10.1038/s41419-020-2298-2.

31. Totsuka K, Ueta T, Uchida T, Roggia MF, Nakagawa S, Vavvas DG, et al. Oxidative stress induces ferroptotic cell death in retinal pigment epithelial cells. Exp Eye Res. 2019;181:316-24. https://doi.org/10.1016/j.exer.2018.08.019.
32. Walia HS, Yan J. Reversible retinopathy associated with oral deferasirox therapy. BMJ Case Rep. 2013;2013:bcr2013009205. https://doi.org/10.1136/ bcr-2013-009205.

33. Munch IC, Traustason S, Olgaard K, Larsen M. Acute macular neuroretinopathy in relation to anti-thymocyte globulin infusion. Acta Ophthalmol. 2012;90(4): e321-2. https://doi.org/10.1111/j.1755-3768.2011.02276.x

34. Chen H, Lukas TJ, Du N, Suyeoka G, Neufeld AH. Dysfunction of the retinal pigment epithelium with age: increased iron decreases phagocytosis and lysosomal activity. Invest Ophthalmol Vis Sci. 2009;50(4):1895-902. https:// doi.org/10.1167/iovs.08-2850.

\section{Publisher's Note}

Springer Nature remains neutral with regard to jurisdictional claims in published maps and institutional affiliations.
Ready to submit your research? Choose BMC and benefit from:

- fast, convenient online submission

- thorough peer review by experienced researchers in your field

- rapid publication on acceptance

- support for research data, including large and complex data types

- gold Open Access which fosters wider collaboration and increased citations

- maximum visibility for your research: over $100 \mathrm{M}$ website views per year

At BMC, research is always in progress.

Learn more biomedcentral.com/submissions 